\title{
A STUDY ON MARKETING MANAGEMENT PRACTICES OF ENTREPRENEURS IN INFORMAL
}

SECTOR

\section{Dr. S.BASKARAN}

Asso.Prof. \& Head, Dept of MBA, HKBK C E.Bangalore - 560 045, rsbkaran@gmail.com

\begin{abstract}
The informal sector plays a significant role in the economy in terms of employment opportunities and poverty alleviation. This sector generates income-earning opportunities for a large number of people. In India, a large section of the total workforce is still in the informal sector, which contributes a sizeable portion of the country's net domestic product. The unincorporated or non-corporate sector has the largest share of national income, manufacturing activities, services, savings, investment, taxes, credit market, employment, forex earnings, etc. Yet it is little understood, dismissed as 'un-organized', 'informal' or 'residual' sector. It is important that the nature and role of this sector are explored to see how it impacts the economy.
\end{abstract}

Keywords: Informal Sector, Unorganized Sector, Informal Economy

\section{INTRODUCTION}

The informal sector represents an important part of the economy and the labour market in many countries, especially developing countries. Measurements of the informal sector are of intrinsic interest in their own right and contribute towards exhaustive measures of gross domestic product (GDP). Considering that the informal sector provides employment for income creation to a large number of poor and contributes significantly to the GDP of many developing countries, as most of the informal sector enterprises do not maintain business accounts.

\section{MARKETING PRACTICES}

The management practices of entrepreneurs in the informal sector are unique and survived the test of time. There is a need to study the management practices in the functional areas of management of the entrepreneurs in the informal sector. Marketing management practices are based on the value systems and ethos unique to India that requires to be theorized.

It is surmised from the above table that 45.9 percent of the respondents are focusing upon the public sector as the main customer of their business and 5.6 percent of the 


\section{Asia Pacific Journals}

respondents are mainly focusing upon big enterprise as their main customer. The main customer in their business as small enterprise of 6.3 percent of the respondents and 37.1 percent of the respondents are focusing on household / individual as the main customer. The respondents are focusing upon the direct exportation as their main customer and 2.1 percent of the respondents are mainly focusing upon the agency as the main customer in their business. It is noted from the analysis that the majority $(45.9 \%)$ of the respondents are focusing upon the public sector as the main customer in their business.

\section{ABOUT THE CUSTOMERS}

\begin{tabular}{|l|l|l|l|}
\hline $\begin{array}{l}\text { S.No } \\
\cdot\end{array}$ & $\begin{array}{l}\text { Opinio } \\
\text { n }\end{array}$ & $\begin{array}{l}\text { No. of } \\
\text { Respondent } \\
\text { S }\end{array}$ & $\begin{array}{l}\text { Percentag } \\
\text { e }\end{array}$ \\
\hline 1 & Regular & 66 & 9.4 \\
\hline 2 & Floating & 106 & 15.1 \\
\hline 3 & Both & 528 & 75.4 \\
\hline & Total & $\mathbf{7 0 0}$ & $\mathbf{1 0 0 . 0}$ \\
\hline
\end{tabular}

It is substantiated from the above table that 9.4 percent of the respondents are having regular customers and 15.1 percent of the respondents are having floating customers in their business and followed by 75.4 percent of the respondents are having both regular and floating customers in their business. It is witnessed from the analysis that the majority $(75.4 \%)$ of the respondents are having both regular and floating customers in their business.

PURPOSE OF CONDUCTING BUSINESS ACTIVITY IN THIS PLACE

\begin{tabular}{|c|c|c|c|}
\hline $\begin{array}{l}\text { S.N } \\
\text { o. }\end{array}$ & Opinion & $\begin{array}{l}\text { No. of } \\
\text { Responden } \\
\text { ts }\end{array}$ & $\begin{array}{l}\text { Percenta } \\
\text { ge }\end{array}$ \\
\hline 1 & $\begin{array}{l}\text { Own } \\
\text { premises }\end{array}$ & 111 & 15.9 \\
\hline 2 & $\begin{array}{l}\text { No } \\
\text { profession } \\
\text { al } \\
\text { premises }\end{array}$ & 114 & 16.3 \\
\hline 3 & $\begin{array}{l}\text { No need } \\
\text { for this } \\
\text { business }\end{array}$ & 87 & 12.4 \\
\hline 4 & $\begin{array}{l}\text { Convenie } \\
\text { nt and } \\
\text { profitable } \\
\text { location }\end{array}$ & 330 & 47.1 \\
\hline 5 & $\begin{array}{l}\text { Unable to } \\
\text { buy } \\
\text { profession } \\
\text { al } \\
\text { premises }\end{array}$ & 47 & 6.7 \\
\hline \multirow[t]{2}{*}{6} & Others & 11 & 1.6 \\
\hline & Total & 700 & 100.0 \\
\hline
\end{tabular}

It is surmised from the above table that 15.9 percent of the respondents are conducting their business activity in their own premises 
and 16.3 percent of the respondents are conducting their business activity in no professional premises. The respondents of 12.4 percent are opined that no need any location for their business activity and 47.1 percent of the respondents are conducting their business activity in the place of convenient and profitable location. The respondents of 6.7 percent are conducting their business activity in other place because unable to buy professional premises and 1.6 percent of the respondents are conducting their business activity in the place for other reasons. It is inferred from the analysis that the majority $(47.1 \%)$ of the respondents are conducting their business activity in the place of convenient and profitable location.

MODE OF SELLING THE PRODUCT / SERVICE

\begin{tabular}{|l|l|l|l|}
\hline $\begin{array}{l}\text { S.No } \\
\cdot\end{array}$ & Mode & $\begin{array}{l}\text { No. of } \\
\text { Respondent } \\
\text { s }\end{array}$ & $\begin{array}{l}\text { Percentag } \\
\text { e }\end{array}$ \\
\hline 1 & $\begin{array}{l}\text { Persona } \\
\text { 1 selling }\end{array}$ & 88 & 12.6 \\
\hline 2 & $\begin{array}{l}\text { Fixed } \\
\text { price }\end{array}$ & 211 & 30.1 \\
\hline 3 & Both & 401 & 57.3 \\
\hline & Total & $\mathbf{7 0 0}$ & $\mathbf{1 0 0 . 0}$ \\
\hline
\end{tabular}

It is observed from the above table that 12.6 percent of the respondents are selling their product or service with their method of personal selling and 30.1 percent of the respondents are selling their product or service with their fixed price and finally 57.3 percent of the respondents are selling their product or service towards their personal selling and fixed price. It is noted from the analysis that the majority (57.3\%) of the respondents are selling their product or service towards their personal selling and fixed price.

HAVING OWN BRAND

\begin{tabular}{|l|l|l|l|}
\hline $\begin{array}{l}\text { S.No } \\
\cdot\end{array}$ & $\begin{array}{l}\text { Opinio } \\
\text { n }\end{array}$ & $\begin{array}{l}\text { No. of } \\
\text { Respondent } \\
\text { s }\end{array}$ & $\begin{array}{l}\text { Percentag } \\
\text { e }\end{array}$ \\
\hline 1 & Yes & 189 & 27.0 \\
\hline 2 & No & 511 & 73.0 \\
\hline & Total & $\mathbf{7 0 0}$ & $\mathbf{1 0 0 . 0}$ \\
\hline
\end{tabular}

It is conjectured from the above table that 27.0 percent of the respondents are having their own brand and remaining 73.0 percent of the respondents are not having their own brand in business. It is witnessed from the analysis that the majority (73.0\%) of the respondents are not having their own brand in business. 
Asia Pacific Journals

NATURE OF TRANSACTIONS

\begin{tabular}{|l|l|l|l|}
\hline $\begin{array}{l}\text { S.No } \\
\cdot\end{array}$ & $\begin{array}{l}\text { Opinio } \\
\text { n }\end{array}$ & $\begin{array}{l}\text { No. of } \\
\text { Respondent } \\
\text { s }\end{array}$ & $\begin{array}{l}\text { Percentag } \\
\text { e }\end{array}$ \\
\hline 1 & Cash & 534 & 76.3 \\
\hline 2 & Credit & 45 & 6.4 \\
\hline 3 & Both & 121 & 17.3 \\
\hline & Total & $\mathbf{7 0 0}$ & $\mathbf{1 0 0 . 0}$ \\
\hline
\end{tabular}

It is extrapolated from the above table that 76.3 percent of the respondents are mainly using the transactions in the way of paying cash and 6.4 percent of the respondents are using transactions in the way of credit and followed by 17.3 percent of the respondents are using the transactions of amount in the method of paying cash and also in credit. It is inferred from the analysis that the majority (76.3\%) of the respondents are mainly using the transactions in the way of paying cash.

MONTHLY INCOME AND LEVEL OF SATISFACTION

The distribution of sample respondents according to the monthly income level of the respondents and level of satisfaction towards informal sector entrepreneurs are shown in the following table.
INCOME PER MONTH AND LEVEL

OF SATISFACTION

TOWARDS BUSINESS

\begin{tabular}{|c|c|c|c|c|c|c|c|}
\hline \multirow[b]{2}{*}{$\begin{array}{l}\text { S. } \\
\text { N } \\
\text { o. }\end{array}$} & \multirow[b]{2}{*}{$\begin{array}{l}\text { Inco } \\
\text { me } \\
\text { per } \\
\text { mont } \\
\text { h }\end{array}$} & \multirow[b]{2}{*}{$\begin{array}{l}\text { No. of } \\
\text { Respo } \\
\text { ndents }\end{array}$} & \multirow[b]{2}{*}{$\%$} & \multirow[b]{2}{*}{$\begin{array}{l}\text { A } \\
\text { ve } \\
\text { ra } \\
\text { ge }\end{array}$} & \multicolumn{2}{|c|}{ Range } & \multirow[b]{2}{*}{$\begin{array}{l}\text { S. } \\
\text { D }\end{array}$} \\
\hline & & & & & $\begin{array}{l}\text { M } \\
\text { in }\end{array}$ & $\begin{array}{l}\text { M } \\
\text { ax }\end{array}$ & \\
\hline 1. & $\begin{array}{l}\text { Belo } \\
\text { w } \\
\text { Rs. } 50 \\
00 \\
\end{array}$ & 155 & $\begin{array}{l}22 . \\
1\end{array}$ & $\begin{array}{l}34 \\
.1\end{array}$ & $\begin{array}{l}23 \\
.0\end{array}$ & $\begin{array}{l}50 \\
.0\end{array}$ & $\begin{array}{l}7 . \\
4\end{array}$ \\
\hline 2. & $\begin{array}{l}\text { Rs.50 } \\
01- \\
1000 \\
0\end{array}$ & 297 & $\begin{array}{l}42 . \\
4\end{array}$ & $\begin{array}{l}37 \\
.5\end{array}$ & $\begin{array}{l}23 \\
.0\end{array}$ & $\begin{array}{l}46 \\
.0\end{array}$ & $\begin{array}{l}4 . \\
2\end{array}$ \\
\hline 3. & $\begin{array}{l}\text { Rs.10 } \\
001- \\
1500 \\
0\end{array}$ & 141 & $\begin{array}{l}20 . \\
1\end{array}$ & $\begin{array}{l}37 \\
.0\end{array}$ & $\begin{array}{l}23 \\
.0\end{array}$ & $\begin{array}{l}45 \\
.0\end{array}$ & $\begin{array}{l}4 . \\
8\end{array}$ \\
\hline 4. & $\begin{array}{l}\text { Rs.15 } \\
001- \\
2000 \\
0 \\
\end{array}$ & 52 & 7.4 & $\begin{array}{l}36 \\
.8\end{array}$ & $\begin{array}{l}23 \\
.0\end{array}$ & \begin{tabular}{|l|}
43 \\
.0
\end{tabular} & $\begin{array}{l}5 . \\
8\end{array}$ \\
\hline 5. & $\begin{array}{l}\text { Rs.20 } \\
001- \\
2500 \\
0\end{array}$ & 30 & 4.3 & $\begin{array}{l}40 \\
.0\end{array}$ & $\begin{array}{l}23 \\
.0\end{array}$ & \begin{tabular}{|l|}
45 \\
.0
\end{tabular} & $\begin{array}{l}3 . \\
9\end{array}$ \\
\hline 6. & $\begin{array}{l}\text { Abov } \\
\mathrm{e} \\
\text { Rs. } 25 \\
001\end{array}$ & 25 & 3.6 & $\begin{array}{l}39 \\
.6\end{array}$ & $\begin{array}{l}36 \\
.0\end{array}$ & $\begin{array}{l}45 \\
.0\end{array}$ & $\begin{array}{l}2 . \\
0\end{array}$ \\
\hline & Total & 700 & $\begin{array}{l}10 \\
0.0\end{array}$ & & & & \\
\hline
\end{tabular}

It is evident from the above table that the level of satisfaction experienced by the respondents of their monthly income of below Rs.5000 ranges 
Asia Pacific Journals

between 23 and 50 with an average of 34.1.

The level of satisfaction experienced by the respondents of their monthly income between Rs.5001-10000 ranges between 23 and 46 with an average of 37.5 and the monthly income of the respondents from Rs.10001-15000 ranges between 23 and 45 with an average of 37.0. On the other hand, the level of satisfaction experienced by the respondents of their monthly income Rs.15001-20000 ranges between 23 and 43 with an average of 36.8 and the level of satisfaction experienced by the respondents of their monthly income Rs.20001-25000 ranges between 23 and 45 with an average of 40.0. Finally, the level of satisfaction experienced by the respondents of their monthly income of above Rs.25001 ranges between 36 and 45 with an average of 39.6. From the analysis it is concluded that respondents of their monthly income Rs.20001-25000 have experienced the maximum level of satisfaction.

\section{CONCLUSION}

In this study the researcher has attempted to provide an insight into the life of informal sector entrepreneurs in Dindigul district. The researcher himself being an informal sector entrepreneur, this research work is rewarding exercise to the researcher to gain more knowledge on successful entrepreneurship. In a developing country like India where the unemployment rate is quite high, where a section of the population is still living in Third-World conditions, where many people are unschooled, without formal qualifications and relatively poor, it is absolutely essential that they be allowed to earn a livelihood by means of an 'easy-toenter' business. Independently, the informal sector entrepreneurs start their business. In most cases, they are having their own idea to run their business. Even though, their business size is small they are satisfied with their regular customers. The profit margin is very low as the operating expenses are also very low. This study of informal sector entrepreneurs in Dindugal showed that the hygiene standard of the products they offered is quite acceptable and that they have enough satisfied customers.

\section{REFERENCES}

1. Arjan M. Lejour, Paul J. G. Tang, The informal sector: a source of growth, CPB Netherlands Bureau for Economic Policy Analysis, 1999 
Asia Pacific Journals

2. Chetan Ghate, The Oxford

Handbook of the Indian Economy,

Oxford University Press Inc. Oxford, New York, 2012.

3. Gavin Grant Maasdorp, The Informal sector: concept and case study, Economic Research Unit, School of Architecture and Allied Disciplines, University of Natal, 1983.

4. Kanagasabapathi.R, Indian Models of Economy, Business and Management, PHI Learning Private Limited, New Delhi, 2009.

5. Friedrich Schneider "Size and measurement of the informal economy in 110 countries around the world", 2002.

6. Giles, David E.A., Measuring the Hidden Economy: Implications for Econometric Modeling, Economic Journal, 109: June, pp. 370 - 380, 1999.

7. Government of India. National Commission for Enterprises in the Unorganized Sector, Task force Report, "Definitional and Statistical Issues”, 2008.
8. Kanagasabapathi. P. Unorganized Finance Sector: The Engine for Economic Growth, Swadeshi Academic Council, Coimbatore, 2002.

9. Vaidyanathan. $\mathrm{R}$ "Successful of Unorganized services" The Hindu Business Line, July 1, 2004.

10. Vaidyanathan. $\mathrm{R}$ "Understanding the Unorganized sector" The Hindu

Business Line, June 3, 2004. 